\title{
A snapshot of public finance research from immediately prior to the pandemic: IIPF 2020
}

\author{
David R. Agrawal ${ }^{1}$ D $\cdot$ Ronald B. Davies $^{2} \cdot$ Sara LaLumia $^{3} \cdot$ Nadine Riedel $^{4}$. \\ Kimberley Scharf ${ }^{5}$
}

Accepted: 7 August 2021 / Published online: 6 September 2021

(c) The Author(s), under exclusive licence to Springer Science+Business Media, LLC, part of Springer Nature 2021

\begin{abstract}
As the COVID-19 pandemic has shaped public policies and government finances, it has also influenced the topics that public finance economists are researching. Because the 2020 International Institute of Public Finance Congress featured papers that were submitted prior to the start of the pandemic, the Congress allows us to reflect on the state of research prior to the pandemic's shock to both fiscal policies and our worldview. In this article, the Editors of International Tax and Public Finance reflect on interesting papers that were presented at this internationally representative conference in public economics. The exercise provides insight on where the field of public economics was heading prior to the pandemic and will provide a yardstick to see how the field evolves in the coming years afterward.
\end{abstract}

David R. Agrawal

dragrawal@uky.edu

Ronald B. Davies

ronald.davies@ucd.ie

Sara LaLumia

s12@williams.edu

Nadine Riedel

nadine.riedel@wiwi.uni-muenster.de

Kimberley Scharf

k.scharf@bham.ac.uk

1 Martin School of Public Policy and Department of Economics, University of Kentucky, 433 Patterson Office Tower, Lexington, KY 40506, USA

2 School of Economics, University College Dublin, Newman Building, Belfield, Dublin 4, Ireland

3 Williams College, Schapiro Hall Rm 206, Williamstown, MA 01267, USA

4 Institute for Public and Regional Economics, University of Münster, Am Stadtgraben 9, 48143 Münster, Germany

5 Department of Economics, University of Birmingham, Edgbaston, Birmingham B15 2TT, UK 
Keywords Public economics $\cdot$ Public finance $\cdot$ Taxation $\cdot$ Expenditures

JEL Classification $\mathrm{H} 1 \cdot \mathrm{H} 2 \cdot \mathrm{H} 3 \cdot \mathrm{H} 4 \cdot \mathrm{H} 5 \cdot \mathrm{H} 6 \cdot \mathrm{H} 7 \cdot \mathrm{H} 8$

\section{Introduction}

Why do we go to conferences? When the COVID-19 pandemic forced many conferences to cancel or to go online, it also forced us to confront the answer to that question. From our perspective, the biggest value in going to a conference such as the International Institute of Public Finance (IIPF) Congress is that it provides a very condensed overview of what the field of public economics looks like and allows us to be exposed to research from a diverse group of scholars around the world. This is a remarkably important form of continuous learning. By having a snapshot of research presented over a short time period, it helps us to see what patterns are arising in both research and policy, including topics, data sources, and methodologies.

Due to the pandemic, the 2020 conference needed to be held online, rather than in beautiful Iceland. Perhaps more than other in-person conferences, the virtual format of the IIPF juxtaposed with the massive shock to our worldview from the pandemic, presented the field to us in a way that drew out the trends and fashions in a way we really hadn't thought of before. This is one of the reasons for this review. The other reason is that there is just so much interesting research being done. Due to added pressures of the pandemic - that have hit some demographics more than othersmany of us have fallen behind on our own work, let alone keeping up with the latest working papers. One of the great things about a large conference is that it allows others to tell you about a paper you really wish you had heard. So this also gives us a forum, as editors of this journal, to let you know about some of the papers that we saw, which we personally thought were informative. ${ }^{1}$ In particular, we want to highlight papers by junior researchers who were hit especially hard by the limited networking and social opportunities created by the pandemic.

The recent pandemic was not the first time that a current event disrupted an IIPF conference. But, relative to the last IIPF conference cancellation, the disruption to the profession was muted by our ability to connect virtually. In 1991, the IIPF was scheduled for Leningrad, USSR. However, the 1991 Soviet coup d'état attempt took place just a couple of days before the start date of the conference. Conference organizers decided to cancel the meeting. There certainly could not have been a virtual IIPF conference in 1991. The cancellation of the conference likely slowed research

\footnotetext{
${ }^{1}$ Please note that we are not writing referee reports on these papers (or making promises about what would happen if they are submitted to International Tax and Public Finance). Instead, these are just a handful of the papers that we saw that, based on their presentation, struck us as important for the field of public finance. And please note- this is a biased sample. Like everyone else, we attended sessions that seemed interesting to us, so what we highlight says as much about our own interests as the field's. Of course, the sample of papers presented at the conference is also not random and may have depended on people's desire to travel to Iceland and, when the Congress went virtual, those whose authors were still willing to present the paper.
} 
much more so than the shift of the conference to an online format in $2020 .^{2}$ Now, as we face disruptions from the pandemic, academic conferences and other scientific communications have proceeded quite smoothly, relative to the effect of canceling an entire conference in 1991 on the field of public finance. Inevitably, technology has dampened the effect of the shock to the profession from COVID-19.

While the pandemic has dramatically affected regulatory policy, health policy, and fiscal policy, it has also shaped the way we think about research and highlighted the need for more work in some areas. Given papers were submitted to the IIPF 2020 by February, and the COVID-19 pandemic did not rise to international prominence until March 2020, the research presented at this Congress represents the last set of new ideas that were not influenced or shaped by the pandemic's shock to our worldview. As a result, similar to Kleven (2018), this provides us with a useful reference point to determine where the field of public economics was heading prior to the pandemic. ${ }^{3}$ This yardstick provides a useful benchmark to determine the undoubtedly lasting impact of the pandemic on the field of public finance. Inevitably, research going forward will be more interdisciplinary as a result of the pandemic, need to grapple with the fiscal pressures created by the pandemic, seek to address important issues of inequality, and focus on the role of decentralization versus centralization in determining optimal policy, especially during a crisis. These are some topics that will be tackled in the 2021 Congress theme.

In looking at the state of public finance immediately prior to the pandemic, we conclude:

1. Administrative data from around the world allow us to study topics that were unable to be answered previously. These administrative datasets are used in a variety of countries and contexts, including in many developing countries, to precisely answer fundamental questions in public economics. The pandemic will likely increase the importance of administrative data as researchers seek to study the host of policies put into place by state and national governments in response to the crisis.

2. Even prior to COVID-19 and the recent racial justice protests throughout the world, public finance economists are tackling important issues related to income and wealth inequality, as well as inequality by gender. The large number of papers on the program focusing on inequality contrasts with earlier conferences that were more focused on issues of efficiency. Even despite these trends, at this Congress, much less attention appears to be focused on issues of racial inequality. We expect the pandemic will only increase the need to study issues of economic (in)equality.

\footnotetext{
2 We thank David Wildasin for reminding us of the cancellation of the 1991 congress due to political turmoil and for his report on the status working 'digitally' then: "The internet was in its comparative infancy in those days: we had email (still something of a novelty then) but MIME attachments had not yet arrived and Mosaic (first web browser) was not yet available. (When I started using email in the 1980s, I would copy a TeX file in plain text into an email message to send to co-authors who could then run TeX on the text on their computers to see the output; no .pdf attachments!)".

${ }^{3}$ Kleven (2018) focuses on NBER working papers over time. In contrast, we focus on the IIPF, which is more internationally diverse. We do not focus on changes over time, but rather a simple snapshot in time.
} 
3. Even before the pandemic, many papers feature coauthors across multiple fields, with researchers in public economics teaming up with experts in health economics, industrial organization, urban, international trade, labor economics, macroeconomics, or economic demography. Perhaps not appreciated as much, are collaborations outside of economics - with political scientists, lawyers, sociologists, epidemiologists, or public health scholars, etc. The pandemic highlights the need for a broader perspective.

4. Surveys, as a means of understanding attitudes toward government policies or redistribution, are becoming an important part of public finance research. More generally, the use of surveys fits with numerous papers tackling behavioral public economics issues. Researchers during the pandemic have begun using these surveys to shed light on the future of telework or perceptions of regulatory policies.

5. Although good theory is extremely important, empirical public economics has displaced theoretical public finance in terms of the sheer number of papers presented on the program. At the same time, we are heartened by several papers that attempt to tightly link both theory and empirics - this is a skill that is not appreciated enough. We hope many authors attempt to combine a unique blend of theory and empirics in future work. Faced with uncertainty from a massive shock, good theory is important to generating useful predictions and good empirics is useful for making our theories more realistic.

Against that backdrop, in this article, we proceed in three steps. First, we summarize the International Tax and Public Finance (ITAX) PhD Student Award that was given at the 2020 Congress. Second, ITAX's 2020 editors, Ron, Sara, and Kim summarize some of their thoughts from the 2020 Congress. Finally, ITAX's new 2021 editors, David and Nadine, summarize some of their reflections. ${ }^{4}$

\section{IIPF PhD student award winner: Thiago Scot}

The ITAX award for the best paper presented by a $\mathrm{PhD}$ student ${ }^{5}$ was given to Thiago Scot of the University of California - Berkeley for his paper "Corporate Taxation and Evasion Responses: Evidence from a Minimum Tax in Honduras" (Lobel et al., 2020). With 62 submissions, many of which were very strong, choosing a single winner was not easy. This paper initially made the shortlist for two key reasons. First, its focus on corporate tax evasion was very much in step with current events. Although tax evasion has long been a key research area in public economics (Slemrod, 2019), it has become an increasingly important topic of discussion in policy circles and the general public. Second, its use of administrative data and the bunching methodology places the paper's approach at the forefront of research in the field.

What ultimately led us to choose it as the 2020 winner, however, were two key features. First, unlike the bulk of the literature that focuses on the tax minimization

\footnotetext{
4 Ron still remains an editor.

${ }^{5}$ For information on the award, see https://www.iipf.org/itaxaward.html.
} 
efforts of firms in the OECD, this paper looks at those efforts in a developing country. This matters because little is known about whether the lessons learned from developed economies apply to those countries developing their economies. In particular, because the developing world is relatively more reliant on tax revenues generated from corporate income when compared to the OECD, understanding the scale and nature of how tax minimization works in such a context is critical to overhauling international tax rules in an equitable manner. Second - and a key aspect of the IIPF prize - was the excellent presentation delivered by the now, Dr. Scot. The ability to do solid, innovative economic research is one thing; the ability to get across what was done and why it matters in a clear, concise way is another. For the research presented at the IIPF to make the greatest impact, both of these must come together.

We thank all of the authors and presenters who asked to be considered and look forward to continued hard decisions in awarding the prize during the 2021 Congress.

\section{Comments from the 2020 editors-in-chief}

\subsection{Ron's thoughts}

Looking at the congress program, one thing that struck me was the work being done on tax evasion. First, the sheer volume of papers on the topic is impressive. In part, this is stemming from better data. In particular, administrative data are used in Nivala et al. (2020), Lobel et al. (2020), Bazzoli et al. (2020), Leenders et al. (2020), and others. This gives us an ability to directly get at the heart of the issue in a way we have not been able to before. Beyond that, there is growing creativity in how we measure a phenomenon that by its very nature is supposed to be hard to detect.

Estimating Tax Noncompliance Among Self-Employed With Evidence From Pleasure Boat Registers For example, Johannes Hagen presented work using pleasure boat registrations in Sweden and Finland to tease out whether the self-employed (who may be able to evade taxes easier) differ in consumption patterns (Engstrøm et al., 2020). Because they find no differences across groups, this gives them a boost of confidence in using the Pissarides and Weber (1989) method of determining evasion among the self-employed.

Beyond those papers, and perhaps more importantly, there is clearly a rise in interest in the topic. To me, this is most evident by the fact that this year's congress had three sessions titled "Tax Evasion." At the 2015 IIPF congress that I hosted in Dublin, there were no sessions called that. Instead, the papers on tax evasion were included in sessions on, for example, the impact of tax treaties. Why the rise in interest? While better data makes the research easier (although I use that word semi-sarcastically) and events such as the Panama Papers leak have increased public interest in the topic, I see a more fundamental cultural shift in our approach to the issue. In particular, I noticed that we now simply call it "tax evasion," a term that has a clear moral and legal implications, rather than give the taxpayer the benefit of the doubt. In 2015, most papers used the term "tax avoidance" rather than tax evasion to highlight the potential that not all strategies to minimize taxation were illegal. Further, this term steers clear of any moral condemnation of economic 
agents undertaking actions to sidestep tax liabilities. In 2020, however, the preferred term was tax evasion which suggests a violation of the social contract. This suggests a shift in perspective to the topic which is certainly a reflection of the wider public perception that when firms and individuals - particularly those at the top of the income distribution-avoid significant tax liabilities, that this behavior is unfair even when the means used are technically legal. So while the data are still the data and the models must continue to abide by the mathematical rules, this feels like a fundamental change in how researchers engage with the topic that will have an important implication for how we disseminate our academic research to policy makers and the broader public. Perhaps those observations are not surprising given my own research focus on foreign direct investment and international trade, with taxation-and tax evasion-being a key part of the stories I tell.

Tariff Elimination versus Tax Avoidance: Free Trade Agreements and Transfer Pricing Likewise, it probably should not be a shock that one paper I found particularly interesting was Mukunoki and Okoshi (2021), which focuses on the role rules of origin have in transfer pricing. For the non-trade nerd, when a preferential trade agreement (PTA) is formed between two countries and lowers tariffs between them, imports do not automatically qualify for reduced import duties. Instead, rules of origin regulations require the importer to verify that the imported good actually comes from the PTA partner. This is to stop exports from non-partner countries simply being routed through a partner country to avoid the standard tariff. Typically, this is achieved by value-added tests that specify how much of the value must be generated in a partner in order to qualify for reduced tariffs. ${ }^{6}$ For a multinational, this can present an interesting trade-off, particularly when PTA members have high taxes. On the one hand, it can produce outside the PTA and transfer price, incurring high tariffs but low taxes. On the other, it can shift production into a high-tax PTA country which destroys the incentive to transfer price but secures a lower tariff. As such, rules of origin in a PTA can mitigate abusive transfer pricing. Beyond a clever insight, I liked this paper because it shows a clear-cut interaction between international trade and tax policies and highlights how looking at just one can miss important responses to policy.

Optimization Frictions and the Fixed Cost of Proft Shifting Continuing on the topic of transfer pricing, Bilicka et al. (2020) provides an answer to a question that has been bothering me for years. When modeling transfer pricing, the standard approach dates back to Allingham and Sandmo (1972), where the cost of transfer pricing is an increasing function of the gap between the "true" price of the internal transaction and the reported price. This begs all sorts of questions, one of the most important of which is whether those costs are largely variable (which might point to an equilibrium in which all firms cook the books at least a little) or fixed (where only those firms with the most to gain engage in transfer pricing). Using administrative data on profits reported in the UK, the authors examine what happened when

\footnotetext{
${ }^{6}$ It is worth noting that this is a key part of current Brexit problems since goods originating from, say, China that go to the EU pay tariffs once there and then again when entering the UK as they do not contain enough EU value-added to qualify for reduced tariffs.
} 
Italy altered its controlled foreign corporation rules in 2002 and Germany cut its tax in 2008. In both cases, the results point toward changes at the extensive margin (whether positive profits were reported at all) rather than the intensive margin (the size of those profits conditional on them being positive). This then points to a significant role for fixed costs of profit shifting. This matters for two reasons. First, it suggests that profit shifting is mostly driven by a subset of multinationals. ${ }^{7}$ This would then suggest that by targeting a limited number of well-chosen firms, revenue officials may be able to address a significant share of aggregate profit shifting. Second, it would imply that tax policy changes will have very different effects across firms. Going one step further, this provides additional insights into how firm responses to tax policy can result in significant equilibrium effects such as changes to industry concentration (see Martin et al. 2020).

The Elusive Banker: Using Hurricanes to Uncover (Non-)activity in Offshore Financial Centers Of course, no discussion of international tax evasion would be complete without a discussion of tax havens. For me, Miethe (2020) filled this void with a creative and literally "natural" experiment. Among researchers on tax evasion, offshore financial centers such as those found in the Caribbean exist because of their low tax rates. Combined with overall stability and secrecy, this means that they provide a safe, tax free location for profits. These locations, however, are quick to suggest that this is not enough and that their specialized human capital explains the very high profits booked in within their borders. This latter explanation, however, would suggest an overall robust local economy in which local and multinational activity follow broadly similar trends. To test this, Miethe (2020) considers hurricanes that strike different islands at different times and with different intensities (as measured by changes in geospatial nightlight data). Doing so results in two findings. First, international investors respond to the natural disaster only in non-tax havens with no response found in havens. Second, in havens, there is a response by local companies but not by international ones. This suggests that foreign investments in tax havens have little to do with local economic conditions. Beyond using an innovative identification technique (presumably, hurricanes are fairly exogenous to investment patterns), this mirrors the overall mood in which tax avoidance really is evasion, i.e. minimizing taxes for the few without bringing benefits to the many.

Gender Differences in Tax Evasion: Evidence from Norwegian Microdata Moving from firm to household evasion, I found the results of Brun Bjørkheim and Nygård (2020) intriguing. Focusing on self-employed workers in Norway, they use administrative data and the Pissarides and Weber (1989) approach to ask how income underreporting varies by, among other things, gender. The revelation in their results is not that underreporting varies across people, but that it is most prevalent among self-employed women in cohabiting households. If asked, I would have presumed that males would evade the most due to an assumed greater tolerance for risk. As the authors note, however, the results must be interpreted cautiously because the Pissarides and Weber (1989) methodology assumes identical spending patterns across individuals. If women spend differently (e.g. on charitable giving), this can result in

\footnotetext{
7 Indeed, this is what Davies et al. (2018) find in using transaction level data for French firms.
} 
a mismeasurement of underreported income that varies along with an individual's observable characteristics. Beyond an interesting and surprising result, this matters in a number of ways. First, there are obviously behavioral differences across genders that have been documented in numerous situations and this suggests that tax policy is no different. That matters because it suggests that using nudges and other soft mechanisms may have differential effects on different taxpayers. Second, as with the efficiency gains from focusing enforcement on the firms most likely to shift profits, understanding who to target in individual tax enforcement can increase revenues at minimal cost-whether we want to use that information is another question. Third, although Norway may be well below the OECD average in the gender wage gap, these differentials persist. As workplace equality (hopefully) continues to improve and puts more women in higher income and self-employed positions, understanding their differential approaches to tax compliance can provide better predictions for changes in tax takes.

While I could go on and on about tax evasion, I want to conclude by pointing out two papers on women and politics that I found particularly interesting. Presented back to back, they gave useful insights into the lack of gender diversity at the highest levels of political office.

Gender Gaps in Political Careers: Evidence from Competitive Elections The first was Cipullo (2020) who used the two stage election processes in the US and Italy to examine the political careers of men and women over a long horizon. $\mathrm{He}$ did so in two steps. First, he compares the election success of men and women who barely qualified in the first round of the election process (i.e. marginally won a U.S. primary or just qualified for the run-off election in Italy). In doing so, he finds that such women are 20 to $40 \%$ less likely to be elected than their male counterparts. This initial disparity is only part of the story however because early successes are significant predictors of future successes. Thus, when comparing two candidates who are comparable except for their gender, because men are more successful than women in their early career, this tends to lead to future success and higher office attainment.

A Leaky Pipeline: Recontest Rates and the Underrepresentation of Women in Politics This future success story was then continued in the paper by Baskaran and Hessami (2020), who looked at local election recontesting, i.e. whether a prior candidate even stands in a second election. Using data from Hesse, Germany, they find that female candidates are $5.7 \%$ less likely to run again when compared to comparable male candidates. What is most interesting is that the factor that appears to best explain this gap is the work environment. In places where meetings are frequent and take place in the evenings, the gender gap is largest, suggesting that such practices may be a particular barrier for women council members for whom familial duties take priority.

In listening to these two studies, I couldn't help but draw parallels between political life and academic life. It is undeniable that Economics is currently by-and-large a male-dominated profession. It is also no secret that early publication success, working late into the night, and being gone from home for seminars and conferences are factors that feed into academic success. If there are biases in the referee and editorial process, this bias early in career can also significantly affect gender balance at 
the senior levels of the discipline. Further, if the traditional hallmarks of success are incompatible with home life, this can further freeze out female scholars. With COVID-19 highlighting gender imbalances in the burden of managing home and work (see Zimmer, 2020 for discussion), these seem like lessons for us all to ponder.

\subsection{Sara's thoughts}

When attending a conference in person, it's possible to become deeply immersed in talks and conference events with few reminders of the outside world. Participating in a virtual conference doesn't provide the same kind of escape. (I will sheepishly admit that I propped my laptop near the sink and washed a few dishes during one of the IIPF keynotes.) While I don't want to multi-task during all future conferences, I did appreciate the fact that keeping an eye on the news during the 2020 Congress nudged me to sample from the conference offerings in new ways. The COVID-19 pandemic and the groundswell of social justice activism prompted me to think more about inequality. I found that my attention was particularly drawn to a handful of papers offering new insights into causes of inequality or analyzing policies designed to redistribute income. Several papers expanded my understanding of potential root causes of inequality.

Long-Term Effects of Equal Sharing: Evidence from Historical Inheritance Rules for Land. Bartels et al. (2020) consider the impacts of different types of inheritance laws. In some parts of Germany, 19th century inheritance law dictated that land be divided equally between all of a decedent's children. Other areas mandated that inherited land was not divisible, and that all of a decedent's land must go to a single heir. The authors make use of newly digitized historical agricultural and occupational census data to link these legal regimes with subsequent economic outcomes. They employ a geographic RD design, showing that inheritance rules changed sharply at borders, but that other potential determinants of long run growth are smooth across borders. Not surprisingly, localities requiring land to be equally distributed across heirs experienced a more even distribution of property in the 19th century. These areas industrialized at earlier dates, and in modern data, have higher levels of GDP per capita, labor productivity, and top incomes. Interestingly, these areas with a history of more equal land distribution now have a less equal income distribution, with higher top income shares.

Importing Inequality: Top Income Growth and the Globalization of the Elite. Immigration can influence the level of inequality within a society, and much has been written about the impacts of immigrants on low-skilled labor markets. Advani et al. (2020) turn the focus to the highest earners. They make use of administrative data on taxpayers in the UK, where the algorithm used to generate National Insurance Numbers makes it possible to identify individuals who migrated to the UK at age 18 or older. They find that immigrants are concentrated at the top of the income distribution. The share of migrants in the top $1 \%$ is about 1.4 times the share of migrants in the bottom $10 \%$. Migrants in the top $1 \%$ are primarily earning labor income, more so than capital income, and are heavily concentrated in the finance industry. The authors carry out a 
decomposition exercise to estimate that migration has accounted for $85 \%$ of the growth in the top $1 \%$ income share over the last two decades.

Corporate Taxation and the Distribution of Income. Of course the tax system can affect inequality, sometimes in surprising ways. Hines (2020) points out that an increase in corporate tax rates can increase inequality, even if the corporate tax is borne by (high-income) owners of capital. The mechanism is that a higher corporate tax rate shifts activity from the corporate sector to the noncorporate sector, where idiosyncratic risk is higher. (Corporations spread risk across shareholders in ways that noncorporate entities, such as partnerships, do not.) Those who strike it lucky in risky noncorporate activity become very rich, while those who are unlucky in noncorporate activity fall to a lower income level. This ultimately leads to a more dispersed distribution of income than would have been realized in an economy with more corporate activity.

Many papers on the program analyzed the effects of redistributive policies. Not every policy designed to mitigate inequality necessarily does so.

Who Paid the French 75\% Tax on Millionaires? Guillot (2020) shows that it often not the millionaires themselves. Using a sample of high-income wage earners, she finds that, on average, employers bear more than half of a large, temporary tax increase. There are differences across occupation and sector, with managers bearing a larger share of the tax and athletes bearing much less. Along with using other strategies, high-wage executives re-time the receipt of certain payments to reduce their tax liability.

Family Policies and Child-Related Earnings Gaps in Germany. In this article, policies that are not explicitly redistributive are shown to have important distributional consequences. Bönke et al. (2020) use administrative data to estimate motherhood wage penalties over a long time period, 1949 to 2015, which includes the implementation of several different parental leave policies. Leave policies increase job security for mothers, as intended, but they have made the motherhood wage penalty grow.

Do Left-wing Governments Decrease Wage Inequality? Empirical Evidence Based on Salaries of Civil Servants. Kauder et al. (2020) focus on policy makers rather than on a particular policy. Members of German state governments have the ability to set pay structures for certain types of civil servants, including police officers and judges. Despite rhetoric to the contrary, there is no evidence that left-wing politicians set more equitable salary structures.

Regardless of whether a conference is online or in person, the number of sessions I'd like to attend always far exceeds the number I can actually attend. Thus, it is very possible that I missed it, but I saw little discussion of race. The events of 2020 have helped me to think more about racial justice, both within and outside of the economics profession, and it is a topic I hope to see represented in future IIPF programs-whether virtual or, someday, once again in person.

\subsection{Kim's thoughts}

I did not get to listen to as many presentations as I wanted to at the IIPF 2020 Congress but limited as my experience was, it provided a virtual escape from the grind of pandemic induced isolation. The 2020 IIPF Congress had no papers about the 
economic effects of the pandemic on its program. This is not surprising as the program was not only set far in advance of the actual event, but during the Congress itself, the pandemic was very much ongoing and recent. Certainly, not enough time had passed to allow for the collection and analysis of data concerning its economic effects. Nevertheless, I couldn't help but wonder how the pandemic would affect the answers to some of the questions being asked on the program and how the pandemic would shape the future of public finance research.

My curiosity was further whetted after listening to the Congress' Opening and first Plenary by Ottmar Edenhofer. Edenhofer wove some emerging evidence about how COVID-19 induced lockdowns reduced global emissions, but only to 2006 levels, into his interesting talk on "Pigou in the Post COVID-19 Era-A Tribute on the occasion of the 100th Anniversary of the Publication of The Economics of Welfare." 8 This unexpected positive effect of COVID-19 was not large enough to alleviate the well-known emissions related pressures associated with implementation of Pigouvian remedies, but it pointed to the possibilities that a bit of lemonade might be made from the lemons that the pandemic has presented to the world.

With respect to my own recent research interests on the economics of charity, my thoughts have wandered around questions relating to how the pandemic will affect: individual decisions about whether to donate, how to donate, who to donate to, how much to donate, and when to donate; private and public providers of public goods and services decisions about how much, how, and what to produce; and inequality related tensions caused by changes in the boundaries between the private provision and public provision of public goods and services.

Some musings about the likely effect of the pandemic on individual donation decisions happened in June 2020, just three months after the UK went into the first hard pandemic-induced lockdown. In our article about it, Pinkney and Scharf (2020), rather disingenuously, we thought that because COVID-19 has increased uncertainty about individual's future health/economic outcomes and because it has induced changes in government policies, it would disrupt people's choices! Our reasoning was basic ... COVID-19 induced changes to policy and uncertainty changes people's underlying present/future constraints (income, prices) and expectations so people re-maximize their own utility subject to new constraints/expectations. This leads to new individual optimal choices and a different overall allocation of resources in the economy. Thus COVID-19 has implications for equity/efficiency and overall welfare.

This is where my mind was at when listening to papers from the 2020 IIPF Congress. I enjoyed the papers that I heard, but I really wondered how the pandemic would affect some of the conclusions. Of particular interest to me were Schön (2020) and Di Gialleonardo et al. (2020).

\footnotetext{
${ }_{8}$ A paper based on his talk appears in the special issue of this journal, Edenhofer et al. (2021). In addition to that article, this special issue also features other peer-reviewed papers that were presented at the conference (Acosta-Ormaechea and Morozumi, 2021; Herzfeld, 2021; Lappi, 2021; Mukunoki and Okoshi, 2021; Muthitacharoen et al., 2021; van der Ploeg, 2021) as well as an introduction (ChiroleuAssouline and Runkel, 2021).
} 
The Role of a Pension Fund. Schön (2020) examines the role of state pensions when evaluated against a backdrop of two types of demographic change: increasing life expectancy, and fluctuations in cohort size. Both of these demographic changes imply different types of ageing effects. Increasing life expectancy delivers a slow and steady ageing effect, while in comparison, fluctuations in cohort size translate into faster, less permanent and non-monotonic ageing effects. Each type of ageing effect has a different implication for Pay as You Go (PAYGO) pension plan returns: fluctuating cohort sizes lead to positive returns for some and negative returns for others, while increasing life expectancy has a positive impact on returns. Additional analysis suggests that there is a $1.5 \%$ differential in returns between generations. Mitigating this differential could be achieved by separately targeting the ageing effect and the cohort effect. The former would require an increase in the retirement age in Germany to 81 by the year 2100 (from 60 in the year 1960). The latter effect could be remedied by stabilizing the pension system through a pension fund, which would amount to more than 40\% of GDP were it introduced in 1960.

I really enjoyed this paper. The numbers are quite extraordinary but not surprising, even if they are too big to imagine that such corrections would ever happen in the real world. Working to 81 ? Not me. Now think about the pandemic. Even though it is too early to determine whether COVID-19 has affected life expectancy or cohort size, the kinds of demographic change that we have seen in the past, it has without a doubt generated enormous costs for individuals, firms and public sectors around the world. The Congressional Budget Office in the U.S., estimates the cost of the pandemic to be on the order of 7.6 trillion dollar's worth of lost output over the next decade (Congressional Budget Office, 2020). But this number is just about lost gross domestic product (GDP). When also taking into account the costs of mortality, morbidity, mental health conditions, as well as direct economic losses, the cost leaps to an astounding 16 trillion dollars, or about $90 \%$ of the US' annual GDP (Cutler and Summers, 2020). And other countries are in the same boat. In the UK, government borrowing from April 2020 to 2021 was $£ 299$ billion, the highest figure recorded since records began in 1946, and the Canadian government's spending on COVID-19 measured was $\$ 240$ billion by December 2020 , about eight months into the pandemic. I look forward to future research on the role of pensions, but COVID19 induced pressures on the public finances will surely not permit any kind of blue skies dreams of a world without differentials in PAYGO returns across generations.

The Adequate Rate of Substitution at Retirement and the Role of Pension Funds: Evidence from Italian Data. Di Gialleonardo et al. (2020) addresses the importance of private pension funds in providing an ageing population in supporting the benefits of state pensions. Using Italian data, the authors estimate an adequate net replacement rate range that would allow maintenance of standards of living in old age of $85.60 \%$ to $86.02 \%$. The upshot is that private pension plans are crucial for maintaining a balanced social security system. An immediate inference is that threats to this 'second pillar' (the first being state pensions) would threaten the health of the public finances and/or the well-being of the aged population. But what bigger threat to the stability of the second pillar than COVID-19? People's incomes have been affected by the lockdown and recession. Some have been able to continue fully working from home and may have experienced no change in their income. 
Others will have lost their jobs and will experience a period of unemployment. Others are able to work from home, but because of the general contraction of all sectors of the economy, are not earning as much money as they did previously. Along with changes in income, social distancing requirements have changed the composition of expenditures and the amount of money that is being spent. The overall effect on people's disposable incomes, labor/leisure choices and savings decisions are thus uncertain. In addition, the crisis is likely to have caused a structural shift in people's expectations and in how they discount the future. Contributing factors include uncertainty around how long there will be pressure on health services and equipment, people's health concerns for themselves and their loved ones, the effectiveness of vaccines against variants, uncertainty about future financial market outcomes, and uncertainty about how the public finances will be brought to order. It is not clear how these channels will affect people's labor choices and pension/savings decisions. Evidence from economic research tells us that more uncertainty should lead to more precautionary savings. What this means for the second pillar of the social security system is just not clear.

It remains to be seen what are the effects of the current crisis on the public finances and well-being of humanity, but one thing for sure is that there will be many things to look forward to at future IIPF Congresses, as data becomes available and the pandemic effects (hopefully) wind down and become relegated to history.

\section{Comments from the new editors-in-chief}

\subsection{David's thoughts}

Due to time zone differences as a result of an online format, in addition to family responsibilities at home, I missed being able to see as many papers as I normally would like to see during an IIPF Congress. Thus, I will comment on some papers that I saw at the conference, while also discussing papers that were on the IIPF program that I've seen or heard about in other capacities, such as in seminars or from colleagues. I was struck by the large number of papers on the topic of inequality, but also by the many papers that studied-theoretically or empirically-the effect of policies with redistributive goals. I also appreciate the intersection of economic history and public finance, because by understanding the past, we can better understand the future. While none of the papers below combine theory and empirics, I also appreciated the small number of papers on the program that truly attempted to integrate good theory and empirics.

Information, Ethnic Diversity, and Preferences for Redistribution. In a contribution to the behavioral public finance (Bernheim and Taubinsky, 2018) literature, Foremny (2020) discusses the role of people's misperceptions about the tax law on how individuals think about tax reform. To do this, he conducts a large-scale survey in Spain that documents misunderstandings of marginal versus average tax rates, the tax burden that individuals face, and the level of government responsible for collecting the taxes. He then provides taxpayers with various information treatments in order to see how their views on inequality and redistributive policy change. 
In the context of the survey, he shows that individuals underestimate the marginal tax rate in their survey response relative to "true" tax liability obtained from a tax simulator. Consistent with Gideon (2017), taxpayers appear to confuse the average and marginal tax rates and underestimate their true tax liability. Moreover, although revenue from the personal income tax is split equally between the central government and regional governments in Spain, only $10 \%$ of taxpayers are aware of this split. Most people think that tax revenues disproportionately fund central government revenues.

Taxpayers then receive different treatments. One group is given information that regional governments indeed have the power to change marginal tax rates and that tax revenue is evenly split between regional and central governments. Another treatment shows individuals how much taxes they should have paid for an additional hundred Euros earned.

After the treatment, individuals are then asked about various reform options. After receiving the correct information about their marginal tax rates, individuals are more likely to support more progressive tax reforms. Such a result suggests that people's pre-treatment views on progressivity are influenced by their personal beliefs that their own marginal tax rates are too high. Moreover, individuals that received information on the distribution of tax revenues between the regional and central government are more likely to regard inequality as a problem. This latter view represents an important contribution in a multicultural (and multi-tiered) country with strong regional identities, such as Spain. It suggests that people are more inclined to view inequality as a problem, when they know that the tax revenue funds services for individuals similar to them (i.e. in the same region). See Alesina and Stantcheva (2020) on the role of ethnicity.

The paper represents an important contribution because policymakers often use polling as an influential tool to decide what reforms are politically popular. This paper suggests that any polling numbers may be a result of misinformation and misunderstandings about policy. In turn, the polls that politicians use to shape their views of democracy, and the political platforms they will advocate for, may have substantial error compared to if individuals had perfect information about the tax system. This may lead to even more incremental change than is socially desirable. Thus, if polling is biased as a result of people's own misperceptions, how should politicians use voter preferences to dictate policies? Should polls be used to help make policy? Should governments try to correct this misinformation or does failing to correct for it lead to its own policy goals? These are some of the important questions raised by the analysis in this paper that the literature should address in the future.

Taxing Mobile and Overconfident Top Earners. Against the backdrop of increasing inequality, bonus payment and incentive pay for top earnings has increased dramatically in recent years, as has rent seeking by CEOs (Piketty et al., 2014). At the same time, the behavioral literature suggests that individuals, especially top earners, may overestimate their abilities and are overconfident. Haufler and Nishimura (2020) construct a theoretical model where overconfident managers receive compensation in the form of a fixed wage and a bonus payment, but face a tax rate on the bonus payment. The authors then consider an open economy with 
mobility and study how tax competition for mobile overconfident managers affects the compensation structure for firms and the tax rate that governments set.

The authors first show that the share of the bonus compensation is increasing in the overconfidence of managers. The increased reliance on bonuses thus makes the distribution of income more unequal. Despite increasing the bonuses, higher levels of overconfidence are negatively related to the revenue maximizing bonus tax rates among competing governments. Intuitively, because managers are overconfident, they anticipate paying the bonus tax at a higher probability than they actually would pay the tax, which raises the elasticity of migration. Thus, overconfidence makes labor more mobile in response to expected tax payments. Factoring in this higher elasticity, governments set a lower tax rate on bonuses. Thus, whether revenue rises or falls depends on two offsetting factors: the increased tax base from added reliance on bonuses in contracts and the lower tax rate as a result of higher migration elasticities. The authors show that in their model, the former effect dominates and revenues increase in overconfidence.

Under a more general interpretation of the bonus tax, it can be viewed as an additional tax rate on top incomes. Given research shows that tax systems have become less progressive in recent years (Egger et al., 2019), the authors identify an interesting interaction between increased mobility and behavioral factors such as overconfidence. But, overconfidence may arise along other dimensions. For example, what if behavioral concerns influence people's perceptions about their ability to be caught in the act of tax evasion? Moreover, to what extent do incentive contracts reflect shareholder value theories or rent extraction by managers? In particular, future research might explore whether the effects depend on if incentive contracts are productivity enhancing or are tools for rent extraction. Regardless, given recent trends and the ability of top earners to move across regions, ${ }^{9}$ tax competition remains an important factor influencing the taxation of top earners.

Delaying Retirement and Mortality: Evidence from Pension Reforms. In addition to the income distribution, public policies and government programs can have important consequences on the demographic distribution within countries, which may then affect the solvency of social security programs. Malkova (2020a) studies the effect of major pension reforms, that induce individuals to delay retirement, on mortality rates later in life. The paper is motivated by the fact that many countries around the world have policies that provide financial incentives to delay retirement, and thus knowing how public pensions influence health status and longevity later in life is critical for understanding the long-term policies of aging societies.

The literature linking work at older ages and mortality has not reached a consensus. The paper contributes to the literature, by examining the effect of a voluntary delay in retirement in a historical context. Previous work mostly focused on estimating effects of changing the statutory retirement ages, or providing early retirement options to specific groups of workers. Moreover, the historical perspective that the

\footnotetext{
$\overline{9}$ See, for example, Kleven et al. (2020).
} 
paper takes allows it to study the long-run effects that are essential to make an accurate cost-benefit evaluation of the reform.

To do this, the paper evaluates a 1964 pension reform in Soviet Russia, that provided financial incentives to delay retirement. Before the reform, if pensioners kept working, they kept on average $30 \%$ of the pension. After the reform, pensioners kept on average $56 \%$ of the pension. Men became eligible for pensions at age 60 . Of course, one may be concerned that the pension reform's financial incentives were limited in Soviet Russia, but Malkova (2020b) shows that financial incentives were critical, and these pension reforms increased employment rates by $47 \%$ five years after the reform.

To now study the effect of the reform on mortality, the author digitizes previously unexplored hand-written datasets from the national archives in Russia. The data contain precise internal data from Soviet records on the number of deaths by age, state, and gender. This represents the most comprehensive database of Soviet mortality records, and is an important historical contribution that allows the author to trace out long-run effects of the reform.

The paper exploits a generalized difference-in-differences design by comparing the age cohort that reached the pensionable age of 60 for men after the reform (treatment group) to the age cohort that reached pensionable age prior to the reform (control group), i.e. when they had less financial incentive to keep working, once they became eligible for pensions. Twelve years after the reform, mortality rates went up by $14 \%$ among men, suggesting that working longer had adverse health consequences. Given much of the Soviet economy was in manufacturing and more blue collar jobs, the external validity of the study applies to certain types of occupations, but occupations that are important today in many countries.

Critically, this paper shows that policies designed to encourage people to delay retirement can have unintended consequences on their health status. Although the individuals willingly decide to work longer, they may have imperfect information on the long-term consequences of working longer. Again, misconceptions may play a critical role. The results of this study suggest that policies that delay retirement may not pass a benefit-cost test, especially when considering strenuous jobs. Thus, a standard policy option used to reform old-age support programs may have unintended negative consequences. If the costs of delaying retirement ages are reflected in higher mortality rates, what are other policies that aging societies can adopt to reform their social security systems? Understanding the demographic effects ${ }^{10}$ of public policies remains critical to determining the best policies for the long-term.

\subsection{Nadine's thoughts}

My research productivity slumped during the first COVID-19 lockdown when I shared my home office with our kids. Attending the 2020 congress was one of the first opportunities to breathe some "research air" again and I greatly enjoyed the

10 See Malkova (2018) for a paper that studies the other end of the demographic distribution, fertility. 
many great papers presented. Below I sketch some papers that I particularly liked (but there were many others as well!).

Corporate Taxes and Multi-product Exporters: Theory and Evidence from Trade Dynamics. Flach et al. (2020) study the link between corporate taxes and international trade. While we, by now, have a good understanding of how corporate taxation impacts firm location, investment choices, profit allocation and financing decisions, it is largely unclear if and how they affect firm competitiveness and trade patterns. This gap in the literature is quite striking given that improving the competitive stance of domestic firms in international product markets is one of the most commonly stated policy goals when corporate tax rates are cut.

Flach et al. (2020) introduce tax policy in a trade model of multi-product firms. Producers face tougher competition in export markets with lower corporate tax rates. The model predicts that a lower corporate tax rate in the destination market increases the price elasticity of export demand, as effective production costs of local firms are reduced. Faced with stronger competition, firms that sell to the destination market drop high cost varieties and hence reduce the exported product range. The authors take these predictions to the data and find strong support for their theoretical predictions.

Do Tax Loss Provisions Distort Venture Capital Funding of Start-ups? In another interesting paper, Bührle (2020) assesses how corporate taxation impacts start-ups and venture capital funding. The paper is particularly topical as entrepreneurs and self-employed individuals were hit hard by the COVID-19 crisis and there are considerable concerns among policymakers and academics that company foundation rates may decline in response (from already low levels in many European countries). Instruments that foster start-up activity and entrepreneurship are thus high on policymakers' agendas.

In her research, Bührle (2020) focuses on anti-tax loss trafficking rules, which disallow the use of loss carryforwards after a change in ownership. The rationale for these rules is to prevent abusive transactions, where firms buy bankrupt corporate shells with loss carryforwards to reduce their corporate tax burden. Bührle (2020), in turn, shows that there is a downside to these provisions, as they may impair venture capital funding and the formation of new companies and start-up firms: if, due to the anti-tax loss trafficking regulation, accumulated losses become worthless when venture capital investors exit the company, this lowers company value and therefore incentives to grant venture capital in the first place.

Using rich data on venture capital-funded companies and exploiting variation in anti-loss trafficking rules in European countries, Bührle (2020) finds that strict antiloss trafficking provisions indeed impair venture capital funding, while less restrictive regulations do not exert adverse effects. More mature companies and companies in high-tech industries are reported to be negatively affected.

Tax Evasion, Public Goods and Tax Progressivity: Evidence from Taxing the Ghosts. The 2020 congress program also featured many interesting papers on tax evasion. Tax evasion is a prevalent problem around the world and often hard to tackle as authorities lack appropriate monitoring techniques. Digitization offers new options to shed light on the shadow economy. In this regard, I particularly liked Rubolino (2020), which is on the "Ghost Buildings Program," where Italian 
authorities used high-resolution aerial photographs of the entire country to identify buildings that were not registered on official land registry maps and thus escaped property and income taxation, the waste disposal tax and payment of a registration fee. The program was highly successful and detected more than two million ghost buildings that were hidden from the tax authorities.

Rubolino (2020) shows that the intervention resulted in a significant increase in tax revenue collection at the local level. Rubolino (2020) documents that the intervention changed the composition of the local public revenues: municipal tax collection increased while central government grants shrank (central government reduced transfers to municipalities based on the projected ghost buildings' tax payments). Substituting government grants with tax revenue is shown to affect public spending choices as suggested by political agency models: municipalities, in response to the Ghost Buildings program, spent more resources on schools and less on administration-a finding, which is in line with the notion that spending is geared toward salient spending categories that please voters when revenue is raised through taxes rather than through grant money.

In It Together? Inequality and the Joint Distribution of Income and Wealth in Switzerland. Finally, I appreciated the many interesting papers on economic inequality in the program. The COVID-19 crisis, for me, served as a strong reminder that inequality has many faces: there are inequalities in income, inequalities in wealth, health and unemployment risks, childcare and housework, just to name a few.

Martinez (2020) assesses the interaction of two dimensions of inequality: income and wealth. Martinez (2020) uses rich data from individual tax filings in Switzerland to study the joint distribution of wealth and income. Several interesting descriptive findings emerge. First, she documents a strong positive correlation between wealth and income, especially at the very top (which rejects the narrative of billionaires who only earn little income); second, wealth mobility across time is documented to be significantly smaller than income mobility, especially in the tails of the distribution; third, inter-vivos gifts and inheritances increase intragenerational wealth mobility. But at the same time, there is strong correlation between the wealth rank of those leaving and those receiving an inheritance.

Martinez (2020) discusses implications of these patterns for the design of redistributive taxation, for the design of pension systems and for counter-cyclical fiscal policy. Her research is a great example that even purely descriptive evidence offers very valuable insights for economic policy.

\section{Conclusion}

Where will the field of public economics go from here? How will conferences and the research presented at those conferences be shaped by the pandemic? These are important, but difficult, questions to answer. Many classic issues in public economics will remain important research areas for years to come-a testament to the timeless nature of some questions in public finance. Nevertheless, the pandemic has 
opened up new and interesting questions that public economists can shed light onespecially relating to inequality, welfare implications, and how to optimally design policy responses by using empirically estimated causal estimates. As noted in Wildasin (2021), many questions in public economics remain "open."

As we noted in the introduction, the field of public finance is becoming increasingly broad, drawing inspiration from other fields in economics: health economics, international trade, industrial organization, urban, labor economics, macroeconomics. The writer Samuel Johnson said "Sir, when a man is tired of London, he is tired of life; for there is in London all that life can afford." Our good friend, and a former ITAX editor, David Wildasin often changes this to say "When you are tired of public finance, you are tired of economics; for there is in public finance all that economics can afford." His justification-public economics is like London, because public economics touches on everything (and every field) that economics has to offer. ${ }^{11}$ Our review of the conference program indicates that this is true.

At the same time, public economics could benefit from interdisciplinary research spanning academic disciplines: political science, sociology, law, finance, accounting, public health, etc. Some of this work has already begun, with tax lawyers working with economists to determine taxing rights, tax accountants working with economists on issues of tax evasion, and the pandemic has prompted collaborations with public health and epidemiology scholars. We have much to contribute to these other disciplines, and we have much to learn from them.

We were impressed with how the IIPF congress featured so many papers at the crossroads of public finance and a different field in economics. It is refreshing to see the conference being used as a vehicle to break down field-based silos in the discipline of economics. We hope future congresses can break down those silos at an even broader academic level to shed light on important topics.

We were also impressed by papers that combined theory and empirics. In this way, theory provides useful empirical predictions or sheds light on identification strategies, and the empirical analysis provides empirical results that allows authors to refine the theory to make it more realistic. We hope future work will have an ever tighter link between theory and empirics, including author teams that draw from both backgrounds.

Finally, one of the most refreshing aspects of the IIPF Congress is the participation from scholars across many different countries of the world. Given the importance of institutions, and the details of country-specific policies, we also appreciated the work on the Congress program that featured multi-national and sometimes multi-continent research teams. The field of public economics is better and more diverse because of these collaborations.

We hope to see you at the next Congress of the IIPF conference!

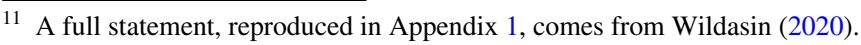




\section{Appendix 1}

\section{Public Finance: The "London" in the World of Economics}

This section presents Wildasin (2020)'s version of Samuel Johnson's quote “Sir, when a man is tired of London, he is tired of life; for there is in London all that life can afford." Legend has it that Wildasin first rephrased this quote when he was giving an introductory lecture about public finance for an audience of incoming $\mathrm{PhD}$ students at Vanderbilt, ca. 1994, attempting to convince them to take public economics over other fields. Since then, one variant or another, has been used by others in the profession. We reproduce it here because it is quite apt for our survey and because it resonates with us.

Wildasin (2020) paraphrases:

Boswell asked Samuel Johnson about public finance: "Is it interesting?"

Johnson replied, "The happiness of public finance is not to be conceived but by those who have studied it."

Boswell: "Why, sir, you find nobody at all intellectual who is willing to depart from the study of public finance?"

Johnson: "No, Sir. When you are tired of public finance, you are tired of economics; for there is in public finance all that economics can afford."

Wildasin (2020) concludes, "public finance brings us into contact with every subfield of economics: labor, economics of the family, IO, macro/monetary, urban, health, education, finance, history, political economy, international,-you name it!

And into contact with law, accounting, business, political science, sociology ... using every conceivable tool in our collective analytical toolkits!

What a privilege to work in such a rich field!"

\section{References}

Acosta-Ormaechea, S., \& Morozumi, A. (2021). The value-added tax and growth: Design matters. International Tax and Public Finance. https://doi.org/10.1007/s10797-021-09681-2.

Advani, A., Koenig, F., Pessina, L. \& Summers, A. (2020, August). Importing inequality: Top income growth and the globalization of the elite. Working Paper.

Alesina, A. \& Stantcheva, S. (2020). Diversity, immigration, and redistribution. NBER Working Paper 26620.

Allingham, M., \& Sandmo, A. (1972). Income tax evasion: A theoretical analysis. Journal of Public Economics, 1(3-4), 323-338.

Bartels, C., Jäger, S. \& Obergruber, N. (2020, August). Long-term effects of equal sharing: Evidence from historical inheritance rules for land. Working Paper.

Baskaran, T. \& Hessami, Z. (2020, August). A leaky pipeline: Recontest rates and the underrepresentation of women in politics. Working Paper.

Bazzoli, M., DiCaro, P., Figari, F., Fiorio, C. \& Manzo, M. (2020, August). Size, heterogeneity, and distributional effects of self-employment income tax evasion in Italy. Working Paper.

Bernheim, B. D., \& Taubinsky, D. (2018). Behavioral public economics. Handbook of Behavioral Economics, 1, 381-516.

Bilicka, K., Devereux, M., \& Güceri, I. (2020, August). Optimization frictions and the fixed cost of proft shifting. Working Paper.

Bönke, T., Glogowsky, U., Hansen, E., Luethen, H. \& Sachs, D. (2020, August). Family policies and child-related earnings gaps in Germany. Working Paper. 
Brun Bjørkheim, J. \& Nygård, O. (2020, August). Gender differences in tax evasion: Evidence from Norwegian microdata. Working Paper.

Bührle, A. T. (2020, August). Do tax loss provisions distort venture capital funding of start-ups? Working Paper.

Chiroleu-Assouline, M., \& Runkel, M. (2021). Introduction to IIPF 2020 special issue in ITAX - Reflections on the interactions between environmental economics and public finance. International Tax and Public Finance. https://doi.org/10.1007/s10797-021-09697-8.

Cipullo, D. (2020, August). Gender gaps in political careers: Evidence from competitive elections. Working Paper.

Congressional Budget Office. (2020). An update to the economic outlook: 2020 to 2030. Washington DC.

Cutler, D. M., \& Summers, L. H. (2020). The COVID-19 pandemic and the $\$ 16$ trillion virus. Journal of the American Medical Association, 324(15), 1495-1496.

Davies, R., Martin, J., Parenti, M., \& Toubal, F. (2018). Knocking on tax haven's door: Multinational firms and transfer pricing. Review of Economics and Statistics, 100(1), 120-134.

Di Gialleonardo, L., Mare, M., Motroni, A., \& Porcelli, F. (2020, August). The adequate rate of substitution at retirement and the role of pension funds: Evidence from Italian data. Working Paper.

Edenhofer, O., Franks, M., \& Kalkuhl, M. (2021). Pigou in the 21st century: A tribute on the occasion of the 100th anniversary of the publication of The Economics of Welfare. Internatinal Tax and Public Finance. https://doi.org/10.1007/s10797-020-09653-y.

Egger, P. H., Nigai, S., \& Strecker, N. M. (2019). The taxing deed of globalization. American Economic Review, 109(2), 353-390.

Engstrøm, P., Hagen, J. \& Johansson, E. (2020, August). Estimating tax noncompliance among selfemployed with evidence from pleasure boat registers. Working Paper.

Flach, L., Irlacher, M. \& Unger, F. (2020, August). Corporate taxes and multi-product exporters: Theory and evidence from trade dynamics. Working paper.

Foremny, D. (2020, February). Information, ethnic diversity, and preferences for redistribution. Working paper.

Gideon, M. (2017). Do individuals perceive income tax rates correctly? Public Finance Review, 45(1), 97-117.

Guillot, M. (2020, August). Who paid the French $75 \%$ tax on millionaires? Effects on top wage earners and their employers. Working Paper.

Haufler, A., Nishimura, Y. (2020, September). Taxing mobile and overconfident top earners. CESifo Working Paper 8550.

Herzfeld, M. (2021). Designing international tax reform: Lessons from TCJA. International Tax and Public Finance. https://doi.org/10.1007/s10797-021-09675-0.

Hines, Jr., J. R. (2020, August). Corporate taxation and the distribution of income. Working Paper.

Kauder, B., Krause, M. \& Potrafke, N. (2020, August). Do left-wing governments decrease wage inequality? Empirical evidence based on salaries of civil servants. Working Paper.

Kleven, H., Landais, C., Muñoz, M., \& Stantcheva, S. (2020). Taxation and migration: Evidence and policy implications. Journal of Economic Perspectives, 34(2), 119-142.

Kleven, H. J. (2018). Slides: Language trends in public economics.

Lappi, P. (2021). Lobbying for size and slice of the quota. International Tax and Public Finance. https:// doi.org/10.1007/s10797-021-09684-Z.

Leenders, W., Lejour, A., Rabate, S. \& vant Riet, M. (2020, August). Offshore tax evasion and wealth inequality: Evidence from a tax amnesty in the Netherlands. Working Paper.

Lobel, F., Scot, T., \& Zuniga, P. (2020, August). Corporate taxation and evasion responses: Evidence from a minimum tax in Honduras. Working Paper.

Malkova, O. (2018). Can maternity benefits have long-term effects on childbearing? Evidence from Soviet Russia. Review of Economics and Statistics, 100(4), 691-703.

Malkova, O. (2020a). Delaying retirement and mortality: Evidence from pension reforms. Working Paper.

Malkova, O. (2020b). Did Soviet elderly employment respond to financial incentives? Evidence from pension reforms. Journal of Public Economics, 182, 104111.

Martin, J., Parenti, M. \& Toubal, F. (2020, August). Corporate tax avoidence and industry concentration. Working Paper.

Martinez, I. Z. (2020, August). In it together? Inequality and the joint distribution of income and wealth in Switzerland. Working Paper.

Miethe, J. (2020, August). The elusive banker: Using hurricanes to uncover (non-)activity in offshore financial centers. Working Paper. 
Mukunoki, H., \& Okoshi, H. (2021). Tariff elimination versus tax avoidance: Free trade agreements and transfer pricing. International Tax and Public Finance. https://doi.org/10.1007/s10797-021-09689-8.

Muthitacharoen, A., Wanichthaworn, W., \& Burong, T. (2021). VAT threshold and small business behavior: Evidence from Thai tax returns. International Tax and Public Finance. https://doi.org/10.1007/ s10797-021-09672-3.

Nivala, A., Harju, J., Kotakorpi, K. \& Matikka, T. (2020, August). Descriptive evidence from risk based tax audits on firms in Finland. Working Paper.

Piketty, T., Saez, E., \& Stantcheva, S. (2014). Optimal taxation of top labor incomes: A tale of three elasticities. American Economic Journal: Economic Policy, 6(1), 230-271.

Pinkney, S. \& Scharf, K. (2020, May). What are the likely effects of the crisis on charitable donations? The Economics Observatory.

Pissarides, C. A., \& Weber, G. (1989). An expenditure-based estimate of Britain's black economy. Journal of Public Economics, 39(1), 17-32.

Rubolino, E. (2020, August). Tax evasion, public goods and tax progressivity: Evidence from taxing the ghost. Working Paper.

Schön, M. (2020, August). The role of a pension fund. Working Paper.

Slemrod, J. (2019). Tax compliance and enforcement. Journal of Economic Literature, 57(4), 904-954.

van der Ploeg, F. (2021). Carbon pricing under uncertainty. International Tax and Public Finance. https:// doi.org/10.1007/s10797-021-09686-x.

Wildasin, D. E. (2020, November). People, places, and public finance. Slides for the annual meetings of the National Tax Association, convened virtually.

Wildasin, D. E. (2021). Open-economy public finance. National Tax Journal, 74(2), 467-490.

Zimmer, K. (2020, June). Gender gap in research output widens during pandemic. The Scientist. https://www.the-scientist.com/news-opinion/gender-gap-in-research-output-widens-during-pande mic-67665.

Publisher's Note Springer Nature remains neutral with regard to jurisdictional claims in published maps and institutional affiliations. 